\title{
Introduction
}

In September 2016, the Twitter hashtag "Tsukamotoyochien" attracted a series of comments on the practices of the Tsukamoto kindergarten, where three- to five-year-olds are educated "according to prewar ideals" (Ha 2016). Apparently, the pupils at the kindergarten are taught to recite the Imperial Rescript on Education (1890) and to bow to the Shōwa emperor's (r. 1926-1989) photograph in the hallways; they are also routinely taken to military bases-all with the explicit aim of preparing them to "protect their nation against potential threats from other countries." One tweet pronounced Japan's democracy to be dying. Another expressed concern that these children were being groomed for direct recruitment into the Self-Defense Forces. Many other comments highlighted a new urgency surrounding issues of children's education and their relationship to the nation-state, all the while commenting on how "sweet," "innocent," and "pitiful" these kindergarteners were.

Since the early 1980 os, Japanese media have teemed with intense debates about bullying at schools, child poverty, child suicides, violent crimes committed by children, the rise of socially withdrawn youngsters, and, most recently, forceful moves by the Abe Shinzō administration to introduce a decisively more conservative educational curriculum (Ogi 2013). While the Twitter storm mentioned above was partly informed by Japan's widely noted right turn, signified in part by the introduction of new security legislation, it also speaks to issues debated in global conversations about the nature of children and how to raise them, the forces and pressures impinging on children, the rights that should be accorded to them, and the responsibilities with which they should be entrusted (Cunningham 1998: 1195; Arai 2016). 
Emotions often erupt when the topic of children is discussed, particularly when further provocations are added to the mix. Across a range of media, in Japan and around the world, current debates reflect and fuel concerns about whether, for instance, children lend themselves particularly easily to the "politics of distraction" (Arai 2016); children are merely "born to buy" (Schor 2005); or, indeed, whether "babies [have come to] rule the world" (Dubinsky 2012: 7). Another set of key questions oscillates along a continuum of concern: why children don't want to grow up (Miller and Bardsley 2005; Kinsella 2013; Cross 2010), whether childhood has dramatically changed to the degree of being irrevocably lost (Field 1995; Fass 2016), or whether the loss is not just that of childhood but, due to an unprecedented demographic crisis, the loss of Japanese children themselves.

\section{THE HISTORY OF CHILDREN AND CHILDHOOD}

Since the time of its 1960 publication, Philippe Ariès's L'Enfant et la vie familiale sous lancien regime and its several subsequent translations have been a touchstone for historians of childhood. Within the discussions the book inspired, one (mis) reading of Aries's "discovery of childhood" was frequently reproduced: that there had been a particular moment at which that discovery occurred. Challenging that interpretation, Michael Kinski (Kinski, Salomon, and Grossmann 2015: 24-25) proposed that the "discovery of childhood" signifies no more (or less) than the dissolution of "the child" and "childhood" as natural and unquestioned things, and challenged us to identify and examine the sites and moments in Japanese history where and when children were thought of, described, and represented as both distinguishable and distinguished from adults. As the chapters in this volume will make apparent, the further back in history one reaches, the harder that moment is to pinpoint. It is the more difficult precisely because the moderns insisted so vehemently on their discovery of childhood. In fact Stefan Tanaka goes so far as to argue that childhood has become a significant symbol or a metaphor for processes inherent to the modern nation-state. In his discussion, the child, children, and childhood become abstractions through which to think about the state's imposition of responsible citizenship on the Japanese people (1997, 2004). In addition, contemporary policymakers, educators, and others worry that true childhood has been lost, and that the conditions under which it supposedly flourished need to be resurrected.

That said, thus far the historiography and ethnography of children and childhood have remained heavily tilted toward the Euro-American sphere. With respect to the historiography of children and childhood in Asia, our fellow scholars in China and Korea studies have begun to overcome this limitation. ${ }^{1}$ Together with a formidable body of scholarship in Japanese (Moriyama and Nakae 2002 and others cited below), the Western-language Japan field has produced a handful of pioneering works, almost all firmly situated in modern/contemporary times. Among 
them are Kathleen Uno's Passages to Modernity: Motherhood, Childhood, and Social Reform in Twentieth-Century Japan (1999); David R. Ambaras's Bad Youth: Juvenile Delinquency and the Politics of Everyday Life in Modern Japan (2005); Mark Jones's Children as Treasures: Childhood and the Middle Class in Early Twentieth-Century Japan (2010); and, more recently, Andrea Arai's The Strange Child: Education and the Psychology of Patriotism in Recessionary Japan (2016). Two recent issues of Japan Forum - “Geographies of Childhood: Japanese Versions of Global Children's Culture" (2006, issue 1, guest ed. Alissa Freedman) and "Children, Education, and Media in Japan and Its Empire" (2016, issue 1, guest ed. Peter Cave)-further demonstrate an emerging field of inquiry. Thus far, the lone exception to the modern/ contemporary bias is the volume Kindheit in der japanischen Geschichte / Childhood in Japanese History (2015), which was edited by Michael Kinski, Harald Salomon, and Eike Grossman and written partly in German and partly in English. Charting the history and historiography of childhood in Japan from the Heian (794-1185) to the Heisei era (1989 to the present), the book highlights the wide spectrum of case studies that demonstrate the preoccupation of Japan scholars with children and childhood during the modern/contemporary periods.

With this book we strive to broaden the disciplinary frame of the debate on children and childhood, not least by assembling the views of scholars in the fields of history, anthropology, religion, film, and cultural studies. Throughout these essays, we also make two interventions. First, we comb prior periods of Japanese history, seeking the feelings and disciplines to which children were subjected in order to highlight modes and conventions of distinguishing children from adults in ways that differ from modern and contemporary preoccupations. And second, we tie the study of children and childhood to analyses of emotions, affects, and sensibilities.

Regarding the first intervention-the historical and anthropological breadth of this volume-we track children's footprints in medieval monasteries and early modern samurai households, inquire about their memories of child's play during war and peace, listen to their quests for family in child welfare institutions, observe them in kindergartens for autistic children, and quietly cheer for them on soccer fields. Taking such a longue durée approach introduces unique challenges with regard to the source bases of our analyses. Our explorations-some traveling far into the early modern past-are made possible by both reading and reading between the lines of letters, diaries, memoirs, family and household records, and religious polemics about promising, rambunctious, sickly, happy, and dutiful youngsters. The literature by people writing about themselves, including their own childhoods and those of their children and grandchildren, constitutes a particularly abundant source.

The further back into the historical record we delve, the more limited is our access. It is worth noting that it was monks, not family members, who first found it necessary to call attention to children in the aggregate in admonitory texts. 
While children are not absent from medieval accounts, they by no means appear as frequently or figure as prominently as they do today. They appear most often in literary accounts, often in ways that expose the workings of the gods in human affairs, sometimes taking on unexpected roles or performing superhuman deeds. In early modern Japan, the publishing industry started producing textbooks and childrearing manuals, woodblock prints and fiction that took children as their themes. Letters and diaries too get us much closer to childhood experiences than ever before. Nonetheless, it is only in modern Japan that magazines for children appear and writings by children survive. Sometimes, representations of children in discourse and film are as close as we can get to comprehending either their experience or how adults might have viewed them at the time, be that as burdensome or useful, or as worthy of love, care, education, reform, or control.

Another difficulty in accessing children's genuine responses to their worlds derives from the source materials themselves, which can embed true expression in the demands of educational institutions, social norms, and the molding power of certain forms of expression. For example, consider school essays and diary entries that children knew would be read by their teachers-and possibly by their parents as well. Of course there is danger in taking such writings as unmediated expressions of their authors' intentions; and yet, it is also true that such expressions do not actually exist. Even if they were made, they were never recorded-or were not preserved in historical documents. Efforts to gain a comprehensive understanding of the young writers' true experience can be additionally limited by the fact that the ethics of fieldwork currently restrict scholars' communication with children (Robertson 2009). Regardless of these methodological and ethical problems, some contributors in this collection have aimed to bring out children's voices. Collectively, we hope that this volume will be followed by many more concerning children and childhood in non-Western parts of the world and in Japan more specifically.

\section{WHEN IS A CHILD A CHILD?}

A history of children and childhood must begin with the question "When is a child a child?" But we could focus our discussion even further by asking, for greater specificity: "At what point does a baby become a child?" "At what point does childhood end?" "When childhood does end, does the child become an adolescent or an adult?" And what of the answers? Even they inspire additional questions. The famous folklorist Yanagita Kunio popularized the notion that in traditional Japan, people believed that children belonged to the gods until age seven-and therefore it behooved parents to not get too attached to them. Historians such as Shibata Jun have argued that Yanagita created this notion, as they can find no evidence for it in the historical record (Shibata 2013; Tanigawa 1996; Kinski, Salomon, and Grossmann 2015). Instead the importance of age seven is that it marks the dividing 
line between the immature child, who is kept close to home, and the more mature child, who is sent out to school, to work, to play. Also, it is worth noting that the seven being referred to is not the Western seven but the old Japanese seven. If a child is one year old (sai) at birth and turns an additional year old at each subsequent new year, then the "seven-year-old" discussed by Yanagita is approximately five or six Western years old.

The question of the age-defined parameters of childhood is particularly fraught for earlier periods. For example, the paucity of viable sources limits the conversations we can have about children before the Edo period (1600-1868). In his chapter, "Nasty Boys or Obedient Children? Childhood and Relative Autonomy in Medieval Japanese Monasteries," Or Porath addresses this difficulty by examining negotiations over what constituted a "child" in religious texts that centered on "children's" behavioral flaws. The Edo period is the setting for two chapters-Luke S. Roberts's “Growing Up Manly: Male Samurai Childhood in Late Edo-Era Tosa" and Anne Walthall's "For the Love of Children: Practice, Affect, and Subjectivities in Hirata Atsutane's Household"-that question our modern assumption that age is the first determinant in defining a child. Both historians propose that age was fungible, that the "end of childhood" for samurai boys and girls varied greatly. Roberts alludes to a trend that finds its exact opposite in the twenty-first century: at the beginning of the nineteenth century, in an effort to mark their sons' social status ever earlier in life and to extend adulthood ever deeper into childhood, young samurai boys were made to wear two swords as markers of adulthood.

From such early modern perspectives, a number of contributors thus question both the modern understanding of the "natural age" of the child and the equally taken-for-granted progression from child to adult through more or less clearly delineated stages. Instead, they propose that the rules of delineation and how these were defined-and, in some cases, defied-have differed dramatically. In some eras, occupational and social status, not age or not age alone, determined what most constituted the boundaries of the child (see also Kawahara 1997). And what of adolescence? Some of the authors in this volume pursue evidence for childhood into the teenage years, suggesting that the boundaries for defining childhood are porous.

Yet another question: How did children learn to be children? Although the documentation is scanty for medieval Japan, it seems likely that, in the monks' eyes, boys learned how to misbehave from other boys. And we should not forget the violence that pervaded seventeenth-century boys' books at a time when the outré behavior they celebrated was already in the past (Kimbrough 2015). Different documents shed different light on this question. W. Puck Brecher (2015) has analyzed images of commoner schoolchildren in late eighteenth- and early nineteenthcentury Japan that depict them making faces behind the teacher's back, chatting, and playing games rather than studying (see also Williams 2012). He reads other 
sources for examples of children's pranks and mock battles-in which though the fighting was pretend the injuries could be all too real. In such games, violence was never far beneath the surface. And since, in his eyes, "childrearing among commoners was intentionally hands-off" (97), the result was that many children got hurt.

Other historians disagree with this "hands-off" assessment, at least for some eras and social statuses. Shibata Jun argues that over the course of Japan's long history an important change emerged in the relationship between adults and children. In medieval Japan, children were essentially ignored, left to grow up on their own. But in the late seventeenth century, the custom of educating children began to spread. By the turn of the eighteenth century, commoner households had become stabilized and their continuity became possible. The famous educator Kaibara Ekiken stated that children are treasures above all else, a belief that pervaded most parts of Japan by the late nineteenth century. And even though scholars of Tokugawa Japan urged parents not to dote on their children, but to raise them with due regard for the future, accounts by foreigners just before and after the fall of the Tokugawa shogunate in 1867 considered Japan a paradise for children, noting how the Japanese neither scolded nor chastised their progeny (Shibata 2013). Not surprisingly, child abuse, of which there was a considerable amount, remained hidden from them as it does from most contemporary Japanese (Mishima 2005).

At the beginning of the twentieth century, we find a new approach to the question of what constitutes a child and how children should be treated. Thanks to advancements in pedagogy, psychology, and medicine, as well as the successes of modern nation-state building, the child became increasingly recognized and embraced as a creature different from the adult. This recognition subsequently set into motion the ongoing tendency to extend childhood as long and as deeply as possible into what used to be considered adulthood. This development in turn brought about the aforementioned emphasis on adolescence as being an essential transition period from child to adult.

In the 1910s and 1920s a range of literary figures, intellectuals, scholars, educators, and reporters proclaimed the child as inherently innocent, and thus demanded and wrote children's literature, founded children's magazines, invented children's toys, and imported (and then produced in Japan) children's clothes that furthered this stance. ${ }^{2}$ Yuan $\mathrm{Xu}$ devoted an entire book to the study of prewar children's comics printed in newspapers (2013). Koresawa Hiroaki did the same for modern educational toys (2009). In her chapter, "Consumer Consumption for Children: Conceptions of Childhood in the Work of Taishō-Period Designers," Jinnō Yuki describes the role of the child and childhood within the flourishing new culture of urban consumption, a theme she has developed at greater length in her book on children and the material culture of modern consumer goods (2011). 
Given the unavoidably partial nature of all records, another question we ask is: Why not observe children at play? Monks of the medieval period (1185-160o) looked upon play with scorn: in their view, acolytes played too hard and too often. Throughout the Edo period (1603-1868), the play of children was rarely noted in diaries written by adults - though they did report gifts of toys that suggest play was encouraged, even if it was deemed not worthy of mention. In the early twentieth century, it was necessary to observe children at play, since unsupervised play could be physically and ideologically risky if children subverted the messages they were taught at school. In a range of documents, play was dismissed as an impediment to children's maturation, exploited as preparation for war, or even embraced as an "arena of propaganda" (Kushner 2009: 245).

Institutionalized child play today contrasts dramatically with that of earlier times. Child play in religious and educational institutions, for instance-never trivial, always ambiguous (Sutton-Smith 1997) - is open to adult direction and indoctrination, and yet it is also a site of (perpetual) child resistance and selfreinvention. And so several contributors have examined sociocultural norms that govern a wide range of children's experiences-as well as how they are reproduced, challenged, and modified within institutions designated for childhood education. Elise Edwards's chapter, "From Grade Schooler to Great Star: Childhood Development and the 'Golden Age' in the World of Japanese Soccer,' steps into one of the many centers of contemporary negotiations about both how child players might eventually morph into adult workers and how proper play at the right age might produce competitive adult players on the soccer field. Play and games, together with affect and emotion, are essential to the reproduction of the norms that other institutions adhere to as well. They are promoted and performed in the child welfare institution that Kathryn E. Goldfarb analyzes in her essay "Food, Affect, and Experiments in Care: Constituting a 'Household-like' Child Welfare Institution in Japan"; they are also central to the educational and therapeutic efforts that preschools for autistic children engage in, as Junko Teruyama describes in her chapter, “Treatment and Intervention for Children with Developmental Disabilities."

\section{CHILDHOOD AND THE STUDY OF EMOTIONS}

In this collection we have viewed the study of children and childhood through a second lens as well. We aim to provide readers with opportunities to engage with the affective education, management, and exploitation of children across different centuries and institutions; to, as it were, put themselves in the shoes of a medieval monk, an early modern samurai grandmother, a mobilized citizen during the Asia-Pacific War, or a victim-critic of nuclear policy in twenty-first century Japan. In so doing, readers can get even closer to historically specific meanings of childhood while also appreciating a twin difficulty that is central to analyses of both childhood and emotions: the assumption of their naturalness and their fleeting 
quality. Even within the same individual, emotions change over time. And, no matter where and when, the child is a liminal figure who moves in and out of her/ his own work and that of adults.

In 1943, Lucien Febvre proclaimed that one could not fully comprehend a period of history without taking into account the emotional character of workaday existence in that period, a standpoint that has been renewed and transformed many times since. ${ }^{3}$ Around the new millennium, a new interest in the study of emotions emerged, manifested, for example, in Ute Frevert's monumental project at the Center for the History of Emotions within the Max Planck Institute for Human Development in Berlin. The two fields of inquiry-the history of childhood and the history of emotions-became explicitly intertwined in the United States when Peter N. Stearns and Timothy Haggerty (1991) described the role of fear and transitions in American "emotional standards for children" in the wake of Stearns's (1985) proclamation of "emotionology" as a new field of inquiry, and their study was advanced by the foundation of the Society for the History of Children and Youth in 2001. Subsequently, challenging the modern bias of "emotionology" that aims to identify emotional standards across American society, Barbara $\mathrm{H}$. Rosenwein (2002, 2007, 2015), by contrast, has coined the notion of "emotional communities." In this volume, we aim to answer her call for "new narratives that recognize various emotional styles, emotional communities, emotional outlets, and emotional restraints in every period," for narratives that "consider how and why these have changed over time."

This volume engages the new history of emotions, particularly children's emotions and emotions that are directed at children, whether by other children or by adults. Our interests parallel those of a growing group of historians around Ute Frevert, a key pioneer in the field, who have examined the various paths, strategies, and conventions that mold the ways children have "[learned] how to feel" (Eitler, Olson, and Jensen 2014; Frevert and Wulf 2012; Frevert 2011). ${ }^{4}$

The studies in this collection address how individual children expressed, managed, and were taken by surprise by their emotions-while also inquiring how ordinary adults, families, media, and other institutions, in aiming to shape how children learned, felt, and formed adult personae, exploited emotions associated with children and childhood for various political goals. Can such expressions ever be simply personal and biographical and not at the same time social and cultural? What of those displays of emotion that can be either genuine or feigned? When people broadcast emotion to the world is it an expression of their internal state? Or is it contrived in order to fulfill social expectations? It might seem that our attention to the senses inevitably leads to children, whose experiences and expressions have often struck adult observers as less mediated, more natural, and more uninhibited by the norms of language (Eustace et al. 2012). After all, one of our key challenges is getting direct information from children themselves rather than relying on adult perceptions, recommendations, and adult-created artifacts. 
In this field, too, the existing body of research regarding things Japanese is distinctly modest. As much as the stoic suppression of emotion is widely associated with Japanese culture in the broadest terms, we know little about even the ritualized expression of emotion in religious contexts - and we know next to nil about emotions related to or expressed by children (Ebersole 1989, 2000, 2004; Bolitho 2003). For instance, Walthall finds that, though samurai grandparents might be well aware of the necessity of controlling their feelings as one of their class's key conventions, their training did not keep them from writing of the tears they shed over missing their grandchildren. The concept of loving children, something that today feels uncomplicated, was previously often tied with status and the future of a household, feared as a weakness (particularly in men), and yet expressed in letters and diaries. The language of love among children, according to Roberts, was freely used when boys were in love with each other, but not in heterosexual constellations. Only in the modern period was the love of children contemplated as a natural bond that connected children to their parents-to their mothers in particular-while also rendering loving mothers politically and legally powerless (Burns 2014).

And yet, the child's symbolic value increased to become hyper-visible as a figure that represents humanity and modernity, as Tanaka proposes for childhood more generally (1997). Harald Salomon argues as much in his chapter, "Children in the Wind': Examining the Golden Age of Childhood Film in Wartime Japan." At the same time, perhaps more than during any other time in the twentieth century, children became political actors-or, at least, were exploited as such; this is the proposition of both Koresawa Hiroaki, in a chapter titled "Children and the Founding of Manchukuo: The Young Girl Ambassadors as Promoters of Friendship" and Sabine Frühstück in "AAnd my heart screams': Children and the War of Emotions." Frühstück then carries her analysis into the postwar period. Yet even during the 1930s and 1940 s children continued to embody remnants of human wildness and antimodernity, resisted adult supervision and control, and did not assume their place in society without a fight or, at least, vivid expressions of resentment, according to Aaron William Moore in "Reversing the Gaze: The Construction of 'Adulthood' in the Wartime Diaries of Japanese Children and Youth."

Similarly, in "Outdoor Play in Wartime Japan," L. Halliday Piel finds that aging adults who were children of the Asia-Pacific War remember the joys of outdoor play as children of any time might-despite ever-present fear and sorrow and anguish concerning death and the possibility of death. Piel's findings also highlight that, though children prior to the modern period frequently experienced the death of young siblings, we know next to nothing about their emotional responses to those experiences - other than through the recollections of adults (Childs 1991).

Norma Field has aptly noted how, during the Asia-Pacific War, the notion that children were children to their parents and "little citizens" of the empire, at the same time that their parents were "children" of the emperor father figure, 
symbolized "an obliteration of childhood through its universalization" (1995: 66; see also Yamanaka 2002). But what about the encouragement "to think and feel like a child" in the anti-nuclear movement of the twenty-first century, as Noriko Manabe asks in her essay, "Monju-kun: Children's Culture as Protest." Worth noting as well is that this important symbol of winsome suffering is gendered male, which leads us to Imada Erika's (2003) insights on what it means when children's gender is left unspecified. One consequence is that boys come to the fore, whether the discussion is of impressing human emotions on nuclear power plants or of rallying the children of China, Manchukuo, and Korea to the Japanese cause, as in prewar propaganda. Perhaps the modern propensity to assume that children's expressions, sentimentality, and emotionality are "natural" is precisely why they are easily exploited for political effect.

Defining the boundaries of "childhood" is an ongoing project, one that is continuously modulated by entrepreneurs of children's products, scholars, and educational, legal, and political institutions, as well as by children themselves. Within these modulating definitions, two angles remain front and center: the assumed inherent innocence of the child, and the adult will to exploit the versatility of the child in the service of a range of problems and positions. Within this process, no matter how much adults strive to sympathize with the child, the delineation between children and adults increases all the more. As such, all inquiries about children's experiences necessitate an unbiased examination of the ways that children's emotional lives have been appropriated as ideological and symbolic manifestations of power.

The diverse essays in this volume-which for the most part cluster around certain periods, in particular the second half of the Tokugawa period, wartime Japan, and the present-are presented chronologically. We begin with three essays that move from Buddhist monasteries in medieval Japan to the multigenerational homes of samurai families in the early modern period. Covering the early twentieth century, another set of essays sheds light on how interior design, film, and the efforts of what we might call "soft power colonization" have envisioned children. Under the specter of the Asia-Pacific War, diaries and children's books and magazines provide clues about how children envisioned adulthood, how they played, and how their "emotional capital" became a concept that survived both war and defeat. Finally, speaking to the concerns of contemporary Japan are four essays that center on play and discipline, norms, and, again, the political uses of not quite "the child" but the remnants of the modern conception of "the child": innocence, harmlessness, and vulnerability. In thus traversing this collection through the chronologic lens, the reader is able to spend time in different emotional communities at work in the same historical moment, in and outside different institutional frameworks and constraints, and across a range of textual records-all with the aim of getting 
as close as possible to the multifaceted, elusive and changing natures of children and childhood.

\section{NOTES}

1. Key works include those by Anne Behnke Kinney (2004), Ping-Chen Hsiung (2005), Vanessa R. Sasson (2013), Orna Naftali (2014, 2016), David M. Promfit (2015), and Dafna Zur (2017).

2. Kristin Holly Williams (2012) has recently suggested that not only were children much more often represented in Edo-period pictures than previously thought, there were also books written for them.

3. More often than not memories of one's childhood are saturated with sensual impressions. They have been the object of study in the longstanding history of the senses and have reemerged within the new history of emotions (Jay 2011; Flint 2014; Reddy 2001). They are loosely intertwined with the history of the senses once contemplated by such thinkers as Lucien Febvre $(1938,1941)$ and Michel Serres (1985) and more recently charted by Alain Corbin (2005).

4. The journal Passions in Context: International Journal for the History and Theory of Emotions emerged from the increased attention to the study of emotions in a wide variety of disciplines including anthropology, history, sociology, political science, legal theory, criminology, economics, cultural studies, and media studies as well as literature.

\section{BIBLIOGRAPHY}

Note: Unless noted otherwise the place of publication for Japanese books is Tokyo.

Ambaras, David. 2005. Bad Youth: Juvenile Delinquency and the Politics of Everyday Life in Modern Japan. Berkeley: University of California Press.

Arai, Andrea. 2016. The Strange Child: Education and the Psychology of Patriotism in Recessionary Japan. Stanford, CA: Stanford University Press.

Bolitho, Harold. 2003. Bereavement and Consolation: Testimonies from Tokugawa. New Haven, CT: Yale University Press.

Brecher, W. Puck. 2015. "Being a Brat: The Ethics of Child Disobedience in the Edo period." In Values, Identity, and Equality in Eighteenth- and Nineteenth-Century Japan, ed. Peter Nosco, James E. Ketelaar, Yasunori Kojima, 80-109. Leiden: Brill.

Burns, Susan L. 2014. "Introduction." In Gender and Law in the Japanese Imperium, ed. Susan L. Burns and Barbara J. Brooks, 1-19. Honolulu: University of Hawai'i Press.

Childs, Margaret Helen. 1991. Rethinking Sorrow: Revelatory Tales of Late Medieval Japan. Ann Arbor: Center for Japanese Studies, University of Michigan.

Corbin, Alain. 2005. "Charting the Cultural History of the Senses." In Empire of the Senses: The Sensual Culture Reader, ed. David Howes, 128-46. London: Bloomsbury.

Cross, Gary. 2010. Men to Boys: The Making of Modern Immaturity. New York: Columbia University Press.

Cunningham, Hugh. 1998. "Review Essay: Histories of Childhood." American Historical Review 103(4): 1195-1208.

Dubinsky, Karen. 2012. "Children, Ideology, and Iconography: How Babies Rule the World." Journal of the History of Childhood and Youth 5(1): 5-13.

Ebersole, Gary L. 1989. Ritual Poetry and the Politics of Death in Early Japan. Princeton, NJ: Princeton University Press. 
. 2000. "The Function of Ritual Weeping Revisited: Affective Expression and Moral Discourse." History of Religions 39, no. 3 (February 2000): 211-46.

- 2004. "The Poetics and Politics of Ritualized Weeping in Early and Medieval Japan. In Holy Tears: Weeping in the Religious Imagination, ed. Jon Hawley and Kimberley Patton, 25-51. Princeton, NJ: Princeton University Press.

Eitler, Pascal, Stephanie Olsen, and Uffa Jensen. 2014. "Introduction." In Learning How to Feel: Children's Literature and Emotional Socialization, 1870-1970, ed. Ute Frevert et. al., 1-20. Oxford: Oxford University Press.

Eustace, Nicole, Eugenia Lean, Julie Livingstone, Jan Plamper, William M. Reddy, and Barbara Rosenwein. 2012. "AHR Conversation: The Historical Study of Emotions." American Historical Review $117(5)$ : 1487-1531.

Fass, Paula. 2016. The End of American Childhood: A History of Parenting from Life on the Frontier to the Managed Child. Princeton, NJ: Princeton University Press.

Febvre, Lucien. 1938. "Psychologie et histoire," Encyclopédie francaise, vol. 8, La vie mentale. Paris: Société de gestion de l'Encyclopédie francaise.

—. 1941. "La sensibilité et l'histoire: Comment reconstituer la vie affective d'autrefois?" Annales d'histoire sociale 3, no. 1/2: 5-20.

Field, Norma. 1995. "The Child as Laborer and Consumer: The Disappearance of Childhood in Contemporary Japan." In Children and the Politics of Culture, ed. S. Stephens, 51-79. Princeton, NJ: Princeton University Press.

Flint, Kate. 2014. "The Social Life of the Senses: The Assaults and Seductions of Modernity." In The Cultural History of the Senses: In the Age of Empire, ed. Constance Classen, 25-45. London: Bloomsbury.

Frevert, Ute. 2011. Emotions in History: Lost and Found. Budapest: Central European University Press.

Frevert, Ute, and Christoph Wulf. 2012. "Die Bildung der Gefühle." Zeitschrift für Erziehungswissenschaft 16: 1-10.

Frevert, Ute, et al. 2014. Learning How to Feel: Children's Literature and Emotional Socialization, 1870-1970. Oxford: Oxford University Press.

Ha, Kwiyeon. 2016. “Japanese Kindergarten Teaches Students Pre-war Ideals." Reuters, 8 December. www.reuters.com/article/us-japan-education-idUSKBN13 X1UV.

Hamilton, Walter. 2013. Children of the Occupation: Japan's Untold Story. New Brunswick, NJ: Rutgers University Press.

Hsiung, Ping-Chen. 2005. A Tender Voyage: Children and Vhildhood in Late Imperial China. Stanford, CA: Stanford University Press.

Imada Erika. 2003. "Jendā-ka sareru 'kodomo"” [Gendered 'children']. Soshioroji 48(1): $57-74$.

Jay, Martin. 2011. "In the Realm of the Senses: An Introduction." American Historical Review 116(2): 307-15.

Jinnō Yuki. 2011. Kodomo o meguru desain to kindai: Kakudai suru shōhin sekai [Design for children and modernity: The expanding world of goods]. Kyōto: Sekai Shisō-sha.

Jones, Mark. 2010. Children as Treasures: Childhood and the Middle Class in Early TwentiethCentury Japan. Cambridge, MA: Harvard University Asia Center.

Kawahara Kazue. 1997. Kodomokan no kindai [The modern view of childhood]. Chūō Kōron Shinsha. 
Kimbrough, R. Keller. 2015. “Bloody Hell! Reading Boys' Books in Seventeenth-Century Japan." Asian Ethnology 74(1): 133-61.

Kinney, Anne Behnke. 2004. Representations of Childhood and Youth in Early China. Stanford, CA: Stanford University Press.

Kinsella, Sharon. 2013. Schoolgirls, Money and Rebellion in Japan. London: Routledge.

Kinski, Michael, Harald Salomon, and Eike Grossmann, eds. 2016. Kindheit in der japanischen Geschichte / Childhood in Japanese history. Wiesbaden: Otto Harrassowitz.

Koresawa Hiroaki. 2009. Kyōiku gangu no kindai: Kyōiku taishō toshite no kodomo no tanjō [Modern educational toys: The birth of the child as an educational phenomenon]. Nara: Bunkyōdō.

Kushner, Barak. 2009. "Planes, Trains and Games: Selling Japan's War in Asia." In Looking Modern: East Asian Visual Culture from Treaty Ports to World War II, ed. Jennifer Purtle and Hans Bjarne Thomson, 243-64. Chicago: Center for the Art of East Asia, Art Media Resources.

Miller, Laura, and Jan Bardsley. 2005. Bad Girls of Japan. New York: Palgrave MacMillan.

Mishima Akiko. 2005. Jidō gyakutai to dōbutsu gyakutai [Child abuse and animal abuse]. Seikyūsha.

Moriyama Shigeki and Nakae Kazue. 2002. Nihon kodomo-shi [A history of children in Japan]. Heibonsha.

Naftali, Orna. 2014. Children, Rights and Modernity in China: Raising Self-Governing Citizens. Studies in Childhood and Youth. New York: Palgrave Macmillan.

- 2016. Children in China. Cambridge: Polity Press.

Ogi Naoki. 2013 (200o). Kodomo no kiki o dō miru ka [How to view the child crisis]. Iwanami.

Promfit, David M. 2015. Youth and Empire: Trans-colonial Childhoods in British and French Asia. Stanford, CA: Stanford University Press.

Reddy, William M. 2001. The Navigation of Feeling: A Framework for the History of Emotions. Cambridge: Cambridge University Press.

Robertson, Jennifer, ed. 2009. Politics and Pitfalls of Japan Ethnography: Reflexivity, Responsibility, and Anthropological Ethics. London: Routledge.

Rosenwein, Barbara. 2002. "Worrying about Emotions in History." American Historical Review 107(3): 821-45.

- 2007. Emotional Communities in the Early Middle Ages. Ithaca, NY: Cornell University Press.

- 2015. Generations of Feeling: A History of Emotions, 1600-1700. Cambridge: Cambridge University Press.

Sasson, Vanessa R. 2013. Little Buddhas: Children and Childhoods in Buddhist Texts and Traditions. Oxford: Oxford University Press.

Schor, Juliet B. 2005. Born to Buy: The Commercialized Child and the New Consumer Culture. New York: Scribner.

Serres, Michel. 1985. Les cinq sens. Paris: B. Grasset.

Shibata Jun. 2013. Nihon yōji-shi: Kodomo e no manazashi [A history of Japanese children]. Yoshikawa Kōbunkan.

Stearns, Peter N. 1985. "Emotionology: Clarifying the History of Emotions and Emotional Standards." American Historical Review 90, no. 4 (Oct. 1985): 813-36. 
Stearns, Peter N., and Timothy Haggerty. 1991. "The Role of Fear: Transitions in American Emotional Standards for Children, 1850-1950." American Historical Review 96, no. 1 (Feb. 1991): 63-94.

Sutton-Smith, Brian. 1997. The Ambiguity of Play. Cambridge, MA: Harvard University Press.

Tanaka, Stefan. 1997. “Childhood: Naturalization of Development into a Japanese Space." In Cultures of Scholarship, ed. S. C. Humphreys, 21-56. Ann Arbor: University of Michigan Press.

- 2004. New Times in Modern Japan. Princeton: Princeton University Press.

Tanigawa Kenichi. 1996. Nihon minzoku bunka shiryō shūssei dai 24-ken: Kodomo no minzo$k u$-shi [Collection of sources on Japan's folklore culture, vol. 24: Children's folklore]. Sanichi Shobō.

Uno, Kathleen. Passages to Modernity: Motherhood, Childhood, and Social Reform in Twentieth-Century Japan. Honolulu: University of Hawaii Press, 1999.

Williams, Kristin Holly. 2012. "Visualizing the Child: Japanese Children's Literature in the Age of Woodblock Print, 1678-1888." Ph.D dissertation, East Asian Languages and Civilizations, Harvard University.

$\mathrm{Xu}$ Yuan. 2013. Nihon ni okeru shinbun rensai kodomo manga no senzen-shi [A prewar history of children's comics printed in Japanese newspapers]. Duan.

Yamanaka Hisashi. 2002. Kodomo ga shokokumin to iwareta koro [When children were called "little citizens"]. Asahi Shinbunsha.

Zur, Dafna. 2017. Figuring Korean Futures: Writing the Child-Heart in Modern Korea. Stanford, CA: Stanford University Press. 